\title{
Information antecedents of personalisation and customisation in business-to-business service markets
}

Received (in revised form): 19th February, 2003

\section{Debra Zahay}

is an assistant professor and the CADMEF Professor of Interactive Marketing at Northern Illinois University in DeKalb, Illinois. Her research focuses on how firms can facilitate relationships with their customers. She is currently working on projects relating to customer information systems, overall customer data quality and improving response rates from personalisation. She has published in the Journal of Interactive Marketing, Interactive Marketing and several conference proceedings. She holds her undergraduate degree from Washington University in St. Louis, her Master of Management from Northwestern University in Evanston, Illinois, her Juris Doctor from Loyola University in Chicago and her Doctor of Philosophy from the University of Illinois.

\begin{abstract}
Abbie Griffin
is Professor of Business Administration at the University of Illinois, Urbana-Champaign College of Commerce, where she teaches MBA core marketing, new product development and business-to-business marketing. She is also the editor of the Journal of Product Innovation Management, the leading academic journal in the areas of product and technology development and a director of Navistar. Professor Griffin's research investigates means for measuring and improving the process of new product development.
\end{abstract}

\begin{abstract}
Interactive marketing (IM) is an organisationally-held process that uses customer information to customise products and to personalise marketing communications and offers to create relevant dialogues with customers. The 'engine' behind IM is the development and management of a customer database as an organisational capability. This paper uses the extant literature relating to the learning organisation, marketing and information technology, supplemented by field interviews with marketing executives, to develop and operationalise constructs for the IM processes of personalisation and customisation and their customer information management antecedents. The paper develops measures for each construct, tests the validity of these measures statistically and empirically examines the association between these variables. Results indicate that amassing customer 'touchpoint' information is not associated with personalisation and customisation. Customisation activity is associated with the collection of sales force information, personalisation capability with overall data quality, marketing information and the ability to disseminate information throughout the firm.
\end{abstract}

Debra Zahay

Assistant Professor, CADMEF Professor of Interactive Marketing, College of Business, Northern Illinois University, DeKalb, Illinois 60015, USA.

Tel: +815 753 1714; e-mail: debra@zahay.com

\section{INTRODUCTION}

The conceptualisation of marketing is moving from the notion of a one-time exchange to longer-term relationships through ongoing interactions, interactions frequently facilitated by new marketing technologies such as customer databases. ${ }^{1-3}$ Interactive marketing (IM) is formally defined $\mathrm{as}^{6} 1$ ) the ability to address an individual 2) ... gather and remember a response of an individual and 3) $\ldots$ address that individual once 
more in a way that takes into account his or her unique response'. ${ }^{4}$ This definition encompasses both relevant marketing communications as well as individualised products. Achieving individualised interactive relationships therefore can be conceptualised as consisting of personalising communications with customers ${ }^{5}$ and customising products for them. ${ }^{6}$ IM processes often deliver offers and communications electronically, creating ongoing interactions with multitudes of customers. Through personalisation and customisation, firms create and maintain relationships with their most valuable customers, creating a competitive advantage that is durable over time. ${ }^{7}$

For large firms, marketing interactively requires marketing, development, manufacturing and information technology (IT) coordination. Effectively developing and managing customer information database capabilities means that firms can move from a transactions-based mass marketing paradigm back to that of an individualised interactive dialogue, as in the days of the small shopkeeper. Updating the system with information from relevant dialogues with particular customers keeps the firm's knowledge accurate and complete over long time periods, maintaining this capability independent of personnel changes. ${ }^{8-11}$

Partly because firms currently are adopting these capabilities, there has been little empirical research on the information-related antecedents of IM techniques. Indeed, rigorously developed operationalisations of personalisation and customisation are still needed. ${ }^{12-13}$ This research tries to fill this gap by:

— operationalising and developing measures of the IM processes of personalisation and customisation - conceptualising and developing measures for managing customer information

- empirically investigating which aspects of managing customer information are related to achieving increased levels of customisation and personalisation in business-to-business service firms in two industries: software and insurance.

\section{LITERATURE REVIEW AND HYPOTHESIS DEVELOPMENT}

This paper uses existing literature, supplemented by field interviews with marketing executives, to develop and operationalise constructs for personalisation, customisation and customer information management, and to develop hypotheses about the relationship between personalisation, customisation and customer information. Table 1 summarises initial conceptualisations, specific operationalisations and the literature sources from which they were drawn.

One goal for gathering and managing customer information is to enable increased and higher value-added interactions with customers, from both the firm's and customers' perspectives. Increasing the added value of interactions is done through personalising and customising them. ${ }^{14-17}$ These decisions are classified as marketing actions. These actions are strategic marketing decisions that are associated with marketing execution. The authors first review the literature on personalisation and customisation and define these concepts.

\section{Personalisation capability and customisation activity}

Over the last century, marketing communication has evolved from mass advertising (one-way) to direct marketing (two-way) to network forms of IM. ${ }^{18}$ However, the links between customer 
Table 1: Sources of interactive marketing constructs

\begin{tabular}{|c|c|c|c|}
\hline Construct & Conceptualisation & Operationalisation & Literature source(s) \\
\hline \multicolumn{4}{|c|}{ Independent variables: } \\
\hline Acquisition & $\begin{array}{l}\text { The breadth of } \\
\text { information acquired }\end{array}$ & $\begin{array}{l}\text { Responses to different } \\
\text { potential sources }\end{array}$ & Direct marketing literature \\
\hline Quality & $\begin{array}{l}\text { Extent to which data as } \\
\text { stored represent reality }\end{array}$ & $\begin{array}{l}\text { Accurate, consistent, } \\
\text { up-to-date, overall quality }\end{array}$ & Wang and Strong (1996) \\
\hline $\begin{array}{l}\text { Person specificity } \\
\text { sales }\end{array}$ & $\begin{array}{l}\text { Information sales typically } \\
\text { acquires }\end{array}$ & $\begin{array}{l}\text { Contact name, type, } \\
\text { response to contact, } \\
\text { others involved }\end{array}$ & Sampler (1998) \\
\hline $\begin{array}{l}\text { Person specificity } \\
\text { marketing }\end{array}$ & $\begin{array}{l}\text { Information marketing } \\
\text { typically acquires }\end{array}$ & $\begin{array}{l}\text { Marketing offers made, } \\
\text { responded to, method of } \\
\text { contact, time to offer } \\
\text { response }\end{array}$ & $\begin{array}{l}\text { Kohli, Jaworski and } \\
\text { Kumar (1993) } \\
\text { Sampler (1998) }\end{array}$ \\
\hline Dissemination & $\begin{array}{l}\text { Collect and process } \\
\text { information as part of } \\
\text { value-added chain }\end{array}$ & $\begin{array}{l}\text { Circulate customer } \\
\text { documents, spread } \\
\text { important information on } \\
\text { major customers and on } \\
\text { customer purchase } \\
\text { patterns, exchange } \\
\text { customer information } \\
\text { across units }\end{array}$ & \\
\hline \multicolumn{4}{|c|}{ Dependent variables: } \\
\hline $\begin{array}{l}\text { Customisation } \\
\text { activity }\end{array}$ & $\begin{array}{l}\text { Use information from } \\
\text { value-added chain to } \\
\text { create product for } \\
\text { individual customers }\end{array}$ & $\begin{array}{l}\text { Products and marketing } \\
\text { efforts depend upon } \\
\text { customer transaction } \\
\text { information, products are } \\
\text { customised based upon } \\
\text { same }\end{array}$ & $\begin{array}{l}\text { Glazer (1991) } \\
\text { Pine (1993) } \\
\text { Milne and Boza (1998) }\end{array}$ \\
\hline $\begin{array}{l}\text { Personalisation } \\
\text { capability }\end{array}$ & $\begin{array}{l}\text { From interactive } \\
\text { marketing: respond to } \\
\text { customer taking into } \\
\text { account customer's } \\
\text { individual response to } \\
\text { prior communication, } \\
\text { focus on ability to track } \\
\text { response as necessary } \\
\text { for personalisation }\end{array}$ & $\begin{array}{l}\text { Response rate tracked by } \\
\text { programme, segment, } \\
\text { customer }\end{array}$ & $\begin{array}{l}\text { Blattberg and Deighton } \\
\text { (1991) } \\
\text { Deighton (1996) }\end{array}$ \\
\hline
\end{tabular}

information antecedents and personalisation have not been well investigated, particularly in the business-to-business domain. Broadly speaking, personalisation is a specialised flow of interactive communication between parties. ${ }^{19,20}$ Personalisation conceptually is rooted in IM's definition: 'the ability to address an individual... once more in a way that takes into account his or her unique response'. ${ }^{21,22}$ Personalisation capability as conceptualised here includes both responding individually to customer-initiated communications and providing customers with only the firm and product information that they desire.
While personalisation capability involves individualised marketing communications, customisation is developing products and services tailored to a particular customer. ${ }^{23-27}$ Successfully customising products for individuals requires using information that is specific to that customer. Products frequently are customised based on transaction information, however, a customer's internally held information also can be bundled with the product offering to add value. For example, the FedEx package tracking system allows a customer access to its own package information, traditionally held by FedEx, as part of the package delivery service offering. 


\section{Customer information management capabilities}

The proliferation of personalisation and customisation opportunities underpins the ability to gather and use customer information to create communications and products for many distantly-distributed customers' specific needs and preferences. Information systems supporting these IM capabilities and activities are called customer relationship management (CRM), sales force automation and data warehouse systems, among other names. ${ }^{28}$ In this paper the terms data and information are used interchangeably, as is often done in practice. $^{29}$

Useful scales for measuring the ability to manage customer information must be independent of any particular system, focusing on overall information management capability. An understanding of customer information management capabilities is possible by integrating concepts from IT, marketing and strategy. The literature views the organisation as a 'knowledge system,' which engages in certain difficult-to-develop learning activities. Because of the specificity and intangibility of the associated information assets, these capabilities are difficult for others to imitate. Because of their inimitability, these learning processes can be perceived as the most potent potential source of competitive advantage. ${ }^{30}$ Thus, customer information management is a set of capabilities related to customer learning processes that ultimately leads to competitive advantage.

This paper focuses on the four basic types of behaviours associated with developing knowledge systems: information generation (get or acquire), memory (store), dissemination (move) and interpretation (use). ${ }^{31-35}$ Together these capabilities define the firm's ability to manage learning activities related to the customer-based knowledge system that supports IM. Table 1 summarises the literature used to operationalise the initial conceptualisation of the customer information management capabilities. The authors combine the issues of what information firms collect about their customers with how it is stored, as only stored information can be useful. Additionally, this paper jointly considers how information is disseminated and used in the organisation.

\section{Information generation and storage: How, how good and what}

Acquiring and storing information for IM is a constant trade-off between inducing more cost versus increasing learning potential. Three aspects of generation from different literatures could relate to the cost-learning potential trade-off: how information is acquired, ${ }^{36,37}$ how good (data quality) the information is ${ }^{38}$ and the specificity of the information obtained. ${ }^{39,40}$ Much emphasis has been placed in the popular press on acquiring information from various customer-related 'touchpoints', or places where the customer and firm interact. ${ }^{41}$ The more different sources used, the broader the set of information available, but at a higher cost. The more one knows about a customer, the more likely one will be able to personalise communications to them - both providing only the information they want and communicating in the way the customer desires. On the other hand, information for product customisation comes primarily from customers themselves. Thus, it is hypothesised that only personalisation capabilities, not customisation, are related to data breadth.

$\mathrm{H}_{1}$ : As more data from different critical customer interaction points are acquired, personalisation capabilities increase. 
Data quality has been a concern in the context of information processing for a long time, as it directly impacts both cost and learning potential. Quality data first and foremost represent an underlying reality, ${ }^{42}$ and high quality data are expensive. However, customer information must be of good quality before it can be useful to the firm (garbage in, garbage out). Quality does not necessarily depend upon source, and thus is included as an independent construct. It is expected that both personalisation and customisation are predicated on high quality data.

$\mathrm{H}_{2 \mathrm{a}}$ : As the data quality of customer information in the firm increases, personalisation capabilities increase.

$\mathrm{H}_{2 \mathrm{~b}}$ : As the data quality of customer information in the firm increases, customisation activity increases.

Another component of customer information is how specific the information is, as a lack of specificity can impede interaction between two parties. $^{43,44}$ Non-specific information, such as name, address, telephone and fax numbers, can be obtained publicly or commercially and is easily available. More specific information, such as detailed transaction and preference information, may cost more to acquire but also may increase the probability of a repeat purchase if the information leads to better customer understanding. Mass communications can be developed without specific information, but individualised communications and customised products require more details.

Knowledge-specific information is usually 'person specific', that is, it is specific to a particular person, or group of similar people. Some customer information can be found only in the personal records or memories of the sales force. ${ }^{45}$ Other information is known only by marketing. Indeed, this is such a problem that sales force automation and CRM systems were developed precisely to make person-specific information more readily available to people in other functions in the firm. It is expected that information collected by the two different functions will support different capabilities, specifically:

$\mathrm{H}_{3 \mathrm{a}}$ : As more information specific to the marketing area and collected by the firm increases, personalisation capabilities increase.

$\mathrm{H}_{3 \mathrm{~b}}$ : As more information specific to the sales force and collected by the firm increases, customisation activity increases.

\section{Information dissemination: Move and use}

Information gathered and stored in the firm is not fully useful unless it can be disseminated and used throughout the organisation. Even if information can be passed across the organisation, it may not be used by or useful to some who need the knowledge if it has been encrypted or codified such that it is not easily understood by everyone. Market intelligence research shows that the ability to use stored information is at the heart of competitive advantage in marketing. ${ }^{46}$ From the marketing orientation literature, customer information dissemination and use is the ability to transfer information in two dimensions in the organisation: within the entire marketing unit and across functional areas. ${ }^{47}$ Information passing smoothly from one person to another within a function, and from one area to the next, say from R\&D to operations to marketing and sales and back again, increases the likelihood that both 


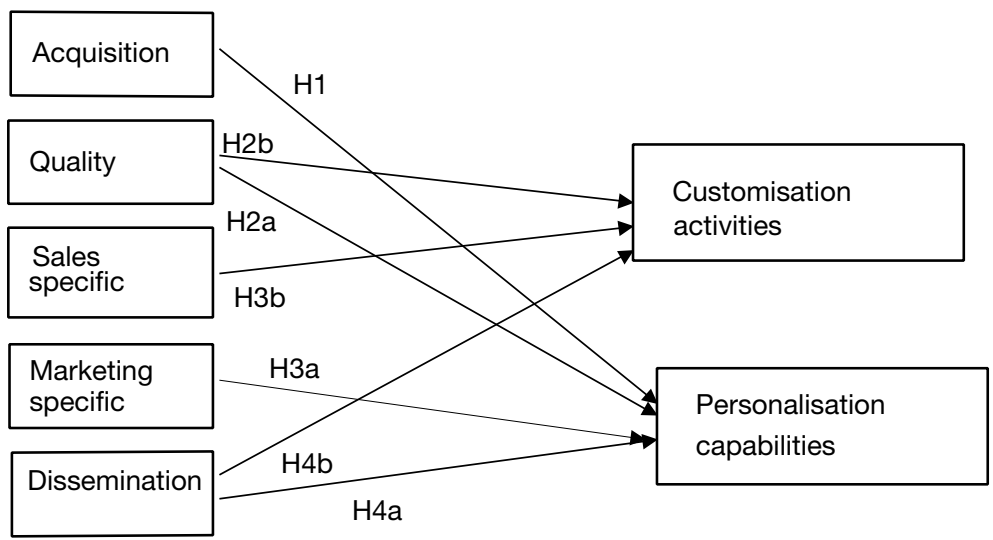

Figure 1: Customer information management capabilities with personalisation and customisation

communications and product offerings meet customer needs.

$\mathrm{H}_{4 \mathrm{a}}$ : As information is more easily disseminated in the organisation, personalisation capability increases.

$\mathrm{H}_{4 \mathrm{~b}}$ : As information is more easily disseminated in the organisation, customisation activity increases.

In summary, information generation and storage is conceptualised as consisting of three distinct components, all of which are necessary to completely characterise the learning behaviour: source of information, quality of stored information and functional specificity of information. Information dissemination is the ability to move information within and across functions. These various aspects of information are somewhat differentially associated with personalisation and/or customisation, as depicted in Figure 1.

\section{METHOD}

\section{Subjects and procedure}

Scale development followed the recommendations of DeVellis. ${ }^{48}$ All phases of development considered the generalisability of the scales for future use beyond the business-to-business services domain. The literature identified in the conceptual development was used as the source of existing scales and potential scale items. While existing scales were used when possible, most had to be developed for this research, as much of the work in this area has been conceptual rather than empirical. Previously developed scales existed for only dissemination and use $\mathrm{e}^{49}$ and customisation. ${ }^{50,51}$

The direct marketing and total quality management literature was used to identify specific items for inclusion in the dimensions of generating customer information. The IT and marketing quality literature suggested a number of common items for assessing quality: accuracy, completeness, consistency, timeliness and relevance. ${ }^{52,53}$ Aspects of information specificity were identified from the direct marketing and relationship marketing literature. The marketing intelligence and marketing orientation literature were the sources of items for information dissemination and use. ${ }^{54}$

Personalisation scale development was inspired conceptually by IM, focusing on the ability to understand the customer's unique responses as a dialogue 
develops. ${ }^{55-57}$ As initial field research (see below) indicated that personalisation capabilities might be under-developed, the scale items concentrated on fairly basic elements of personalisation.

Customisation scale development related to the ability of the business unit to incorporate specific customer transaction information into products, services and marketing efforts as conceptualised by Glazer $^{58}$ and operationalised by Milne and Boza. ${ }^{59}$

Thirty qualitative interviews were held with business-to-business insurance (property, casualty and worker's compensation) and software marketing executives concurrent with the literature review. These interviews guided construct development, particularly those relating to customer information specificity, and supported the appropriateness of the concepts as derived from existing theory. After a telephone pretest, the instrument was paper-and-pencil pre-tested by 47 business-to-business marketing executives from several industries, contacted through professional organisations. ${ }^{60}$ The pretest results were analysed by exploratory factor analysis (principal components method, Varimax rotation) and supported initial scale validity and reliability. The survey was shortened and, finally, a large sample survey was used to test and validate the scales. Data collection methodology and results are reported in the next section and in Appendix 1. Appendix 2 provides specific scale items and indicates which constructs are entirely new and which were adapted from prior research.

Companies were selected from stratified random samples of businessto-business property and casualty insurers (Standard Industrial Classification (SIC) code 6331 and North American Industry Classification System (NAICS) code 524126) and software publishers (SIC code 7372 and NAICS code 51121) from Dun \& Bradstreet and Ward's Business Directory of US Private and Public Companies. ${ }^{61,62}$ These industries were chosen primarily because service industries generally emphasise customer information management more than product industries, which might mean that IM would be more developed in these industries. By choosing one mature (insurance) and one growing (software) industry, scale validity was thought to be higher and more generalisable.

\section{Survey administration and response rate}

One researcher administered the final survey to 209 marketing executives in the software (109) and insurance (100) industries. A business-to-business marketing research firm prescreened respondents to identify those in the business unit knowledgeable about relationships with customers, and how information to manage those relationships is collected and processed. The administration methodology resulted in a response rate of 48 per cent on a company basis (209 of 433 companies) and 31 per cent on a per contact basis (209 of 684 mailed contacts), with nearly identical results by industry.

There were no differences between those who did and did not respond based on year started, total employees or sales $(p>0.05)$. This result was the same pooled or by industry. Average respondent age was 42 with 16 years of business experience. Firms were nearly identical in number of customers but the software firms were younger, with lower sales and fewer employees (Table 2).

\section{Measures}

Correlation analysis was used first, as a guideline for the analysis and to 
Table 2: Respondent and firm profiles

\begin{tabular}{lccc}
\hline Respondents & Insurance & Software & All \\
\hline Respondent age $^{\star \star}$ & 45 & 39 & 42 \\
& $(8.5)^{\star}$ & $(8.4)$ & $(9.0)$ \\
Years worked $^{\star \star}$ & 20 & 13 & 16 \\
Education (\%) graduate school $^{\star \star}$ & $(8.0)$ & $(6.9)$ & $(8.2)$ \\
& $31.2 \%$ & $59.6 \%$ & $46.0 \%$ \\
Firms $_{\text {Sales (millions) }}^{\star \star}$ & & & \\
Employees $^{\star \star}$ & $\$ 501$ & $\$ 97$ & \\
Year started $^{\star \star}$ & 1,381 & 542 & \\
\hline
\end{tabular}

* Numbers in parentheses are standard deviations

${ }^{\star}$ Differences between industries in means significant at $p<0.01$

determine if further scale development would be productive. Exploratory and confirmatory factor analytic techniques helped to reduce the total number of items to 26 out of 51 items in the original survey (Appendix 1). Each of the customer information management scales loaded as predicted (Table 3 ).

Relationships between the final constructs and descriptive statistics are reported in Table 4.

Only four items relating to how information was acquired were retained in the final acquisition construct. The items that explained the variance in responses were the extent to which firms collected responses to web hits/enquiries, responses to e-mails, marketing research survey responses and feedback from customer telephone calls. These items represent some of the most difficult 'touchpoint' information for the firm to acquire. E-mail communication, for example, is quite difficult to manage. Firms struggle with answering consumer e-mails in a timely manner. Final items relating to the quality scale include the extent that people in the business unit found customer information to be accurate, consistent, timely and overall of good quality. Person specificity divided into sales and marketing specificity. Sales specific information that explains variance in the data includes contact name, type of contact, response to the contact and the names of those other than the primary contact involved in the purchase. Marketing specific information relates to marketing offers made, responded to, method of contact and the timing of a response to various marketing offers. The dissemination and use scale measures how well the business unit circulates documents, knows what happens to its major customers, disseminates customer purchase patterns and the extent to which marketing shares customer information with other departments.

The personalisation capabilities scale items relate to the ability to track response rates by programme, customer and segment. These capabilities as measured were cruder than the popular press and practitioner literature would indicate are possible in this area, but reflect the capabilities actually found in a large number of business-to-business services companies. The customisation activities scale includes items about the ability to incorporate customer transaction information into products and marketing efforts, and to customise products using this information.

\section{RESULTS}

Figure 2 and Table 5 present the results of testing the hypothesised relationships 


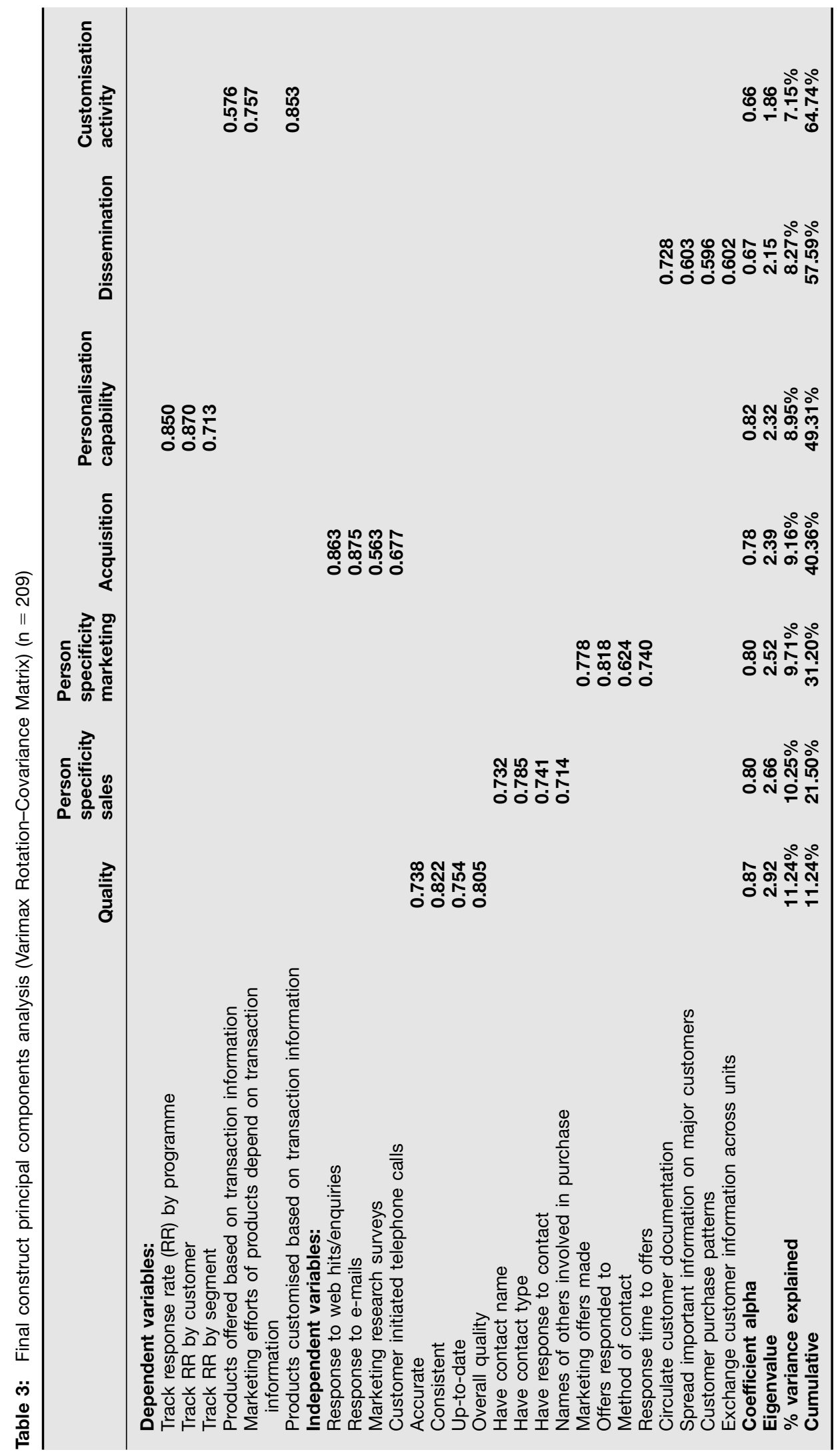


Table 4: Construct descriptive statistics

\begin{tabular}{|c|c|c|c|c|c|c|c|}
\hline & $\begin{array}{l}\text { Customisation } \\
\text { activity }\end{array}$ & $\begin{array}{l}\text { Personalisation } \\
\text { capability }\end{array}$ & Aquisition & Quality & $\begin{array}{l}\text { Sales } \\
\text { specificity }\end{array}$ & $\begin{array}{l}\text { Marketing } \\
\text { specificity }\end{array}$ & Dissemination \\
\hline Customisation activity & $\begin{array}{l}3.52 \\
(0.86)\end{array}$ & & & & & & \\
\hline Personalisation capability & $0.18^{\star \star}$ & $\begin{array}{r}3.30 \\
(1.20)\end{array}$ & & & & & \\
\hline Acquisition & 0.05 & $0.16^{*}$ & $\begin{array}{c}3.03 \\
(1.02)\end{array}$ & & & & \\
\hline Quality & $0.21^{\star \star}$ & $0.36^{* *}$ & -0.013 & $\begin{array}{l}3.60 \\
(0.72)\end{array}$ & & & \\
\hline Person specificity - sales & $0.24^{\star \star}$ & $0.15^{\star}$ & 0.081 & $0.32^{\star *}$ & $\begin{array}{l}3.86 \\
(0.84)\end{array}$ & & \\
\hline $\begin{array}{l}\text { Person specificity } \\
- \text { marketing }\end{array}$ & $0.19^{\star \star}$ & $0.32^{\star \star}$ & $0.162^{*}$ & $0.30^{\star *}$ & $0.43^{\star \star}$ & $\begin{array}{c}3.14 \\
(1.04)\end{array}$ & \\
\hline Dissemination & $0.21^{\star *}$ & $0.35^{\star *}$ & 0.086 & $0.39^{\star *}$ & $0.25^{\star \star}$ & $0.29^{* *}$ & $\begin{array}{l}3.43 \\
(0.81)\end{array}$ \\
\hline
\end{tabular}

Correlations: Two-tailed significance, ${ }^{\star} 0.05$ level, ${ }^{\star \star} 0.01$ level, bold indicates significance.

Numbers on the diagonal are means $(\sigma)$, Range on all variables is $1-5$, where 5 is highest level.

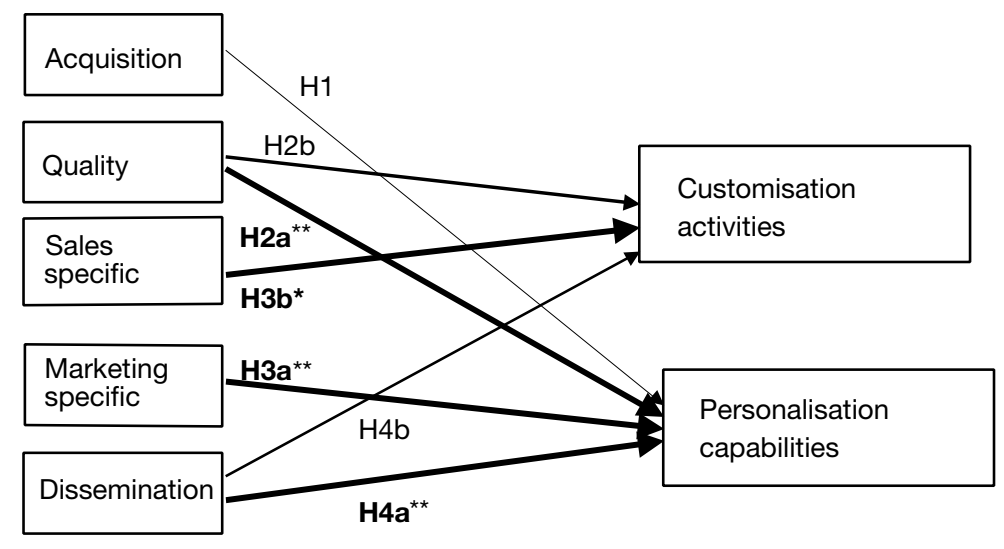

$$
\text { Significance levels: } \begin{aligned}
& \mathrm{p}<0.01= \\
& \mathrm{p}<0.05=
\end{aligned}
$$

Figure 2: Results: Customer information management capabilities with personalisation and customisation Bold indicates significance

between personalisation and customisation and customer information management elements. After checking regression assumptions, the hypotheses were tested using multivariate multiple regression, as the dependent variables were statistically significantly correlated $(\rho=0.18, p<0.01)$. A number of control variables, none of which was significant, were also tested in the equations, ranging from size of firm in terms of sales and employees to aspects of the five forces model, such as threat of substitutes. ${ }^{63}$

Data quality $\left(\mathrm{H}_{2 \mathrm{a}}\right)$, information specific to the marketing function $\left(\mathrm{H}_{3 a}\right)$ and dissemination $\left(\mathrm{H}_{4 \mathrm{a}}\right)$ are all statistically significantly associated with personalisation capability, although acquisition is not $\left(\mathrm{H}_{1}\right)$. Thus, it is not the number of different kinds of information sources that allows personalised interactions, but rather that it comes from the 'right' sources (ie 
Table 5: Multiple multivariate regression results

\begin{tabular}{|c|c|c|c|c|}
\hline & \multicolumn{2}{|c|}{$\begin{array}{l}\text { Personalisation } \\
\text { Std. } \beta \quad t \text { (sig.) }\end{array}$} & $\begin{array}{l}\text { Custor } \\
\text { Std. } \beta\end{array}$ & $t$ (sig.) \\
\hline Constant & 0.070 & $0.14(0.89)$ & 1.847 & $4.70(<0.01)$ \\
\hline Acquisition & 0.135 & $1.82(0.07)$ & 0.020 & $0.35(0.72)$ \\
\hline Quality & 0.382 & $3.27(<0.01)$ & 0.109 & $1.20(0.23)$ \\
\hline Sales-specific information & -0.092 & $-0.92(0.36)$ & 0.164 & $2.12(0.04)$ \\
\hline Marketing-specific information & 0.231 & $2.81(<0.01)$ & 0.050 & $0.78(0.44)$ \\
\hline Dissemination & 0.308 & $3.01(<0.01)$ & 0.124 & $1.56(0.12)$ \\
\hline
\end{tabular}

Variables in bold are significant $p<0.05$

Personalisation: $F$ (sig.) $=12.05(0.000) ; R^{2}=0.23$, Adj. $R^{2}=0.21$; Sample $=209, d f=203$

Customisation: $F$ (sig.) $=4.326(0.001) ; R^{2}=0.010$, Adj. $R^{2}=0.07$

the marketing function), is of high quality and gets transmitted and used by people in multiple functions. The adjusted $R^{2}$ is 0.21 , indicating that, while clearly other variables not measured in this study also relate to the ability to personalise communications, managing customer information in the firm also materially relates.

For customisation activity, only having stored information that is specific to the sales function $\left(\mathrm{H}_{3 \mathrm{~b}}\right)$ is statistically significantly associated. Neither data quality $\left(\mathrm{H}_{2 \mathrm{~b}}\right)$ nor dissemination $\left(\mathrm{H}_{4 \mathrm{~b}}\right)$ relate to a firm's customisation activity, according to these data. Because multiple multivariate regression was used, rather than performing independent regressions, the authors also tested whether acquisition and information specific to the marketing function were related to customisation, and found that, as hypothesised, these variables were not related either. Thus, from these data, having customisation activities in the firm is associated only with having information stored that is sales specific. However, it was also noted that the adjusted $R^{2}$ is much lower for this set of associations: 0.07 . This result indicates that variables other than those operationalising and managing customer information are far more important in enabling customisation activities.

\section{DISCUSSION}

One goal of this research was to develop scales for personalisation, customisation and the various aspects of managing customer information, which were grounded in theory and practice, for use in future studies of relationship marketing, IM and customer information management. This part of the research has, by necessity, been somewhat exploratory. The general hypothesis that learning organisation theory suggests characteristics of the ability to manage customer information has been supported. Customisation activities and personalisation capabilities scales, developed from the relationship marketing and IM literature, also are supported statistically. These scales now can be used in future research. These scales are needed, since academic work in this area largely has been theoretical in nature.

Having a breadth of stored information is not associated with either personalisation or customisation. Additionally, the fact that managing customer information is not particularly highly associated with customisation suggests that merely building large-scale databases to hold and disseminate customer information perhaps should not be attempted before determining the value of the information to the organisation and how the information 
will be used. This result is consistent with literature that suggests that it is not the IT itself, in this case a big data storage capability, that distinguishes between firm capabilities, but the utilisation of IT with complementary human and business resources. ${ }^{64}$

This analysis also suggests that carefully selecting the appropriate information to store, ensuring it is high quality, and organising it so that the right people can access it easily is the key, not just processing of large amounts of data. The importance of data quality in customer information management capabilities indicates that business units must focus on quality.

These results also support the longstanding practice of database and direct marketers of supplementing non-specific information with that specific to a particular customer. It is the very specific, hard to get information (in multiple dimensions) that enables business units to manage customer information to achieve both personalisation capability and customisation activity.

The relative importance of sales force versus marketing information in customisation suggests that implementing sales force automation systems might take precedence over other types of business-to-business marketing applications, if customisation is the goal. Firms may want to focus on managing and making visible information that the sales force controls. On the other hand, if personalisation is desired, the needed information is more likely to be held by marketing. The overall importance of data quality and customer information dissemination in relation to personalisation capability suggests that personalisation is a company-wide function, more so than customisation. These results are consistent with observations from the practice community that organisational factors are critical in the implementation of CRM programmes.

\section{FUTURE RESEARCH AND LIMITATIONS}

The successful future of IM, both academically and practically, may be at least in part associated with managing customer information. These scales are a first step in better understanding this issue and can be used in the future to assess the capabilities of managing customer information within a variety of contexts of IM. Research in areas as diverse as the effectiveness of websites that collect and consolidate information to understanding the overall relationship of these capabilities and firm performance can benefit from the work presented here. These scales also can be adapted and used in the consumer marketing context and may be useful to researchers in IT and strategy.

The overall lack of association of these information antecedents with customisation activity suggests there are other, more important factors than information that enable this marketing capability. One hypothesis is that customisation is related more to the operational processes of the firm. Custom manufacturing capabilities for companies producing hard goods and service process improvements for service companies might be more important for customisation than information processes. These additional antecedents of customisation are potential areas for future research.

Perhaps the most intriguing and perplexing result concerns the acquisition of customer touchpoint information. The capabilities that distinguished companies in the sample related to the ability to capture information from web hits/enquiries, e-mails, marketing 
Table 6: Customer information management characteristics of firms pursuing personalisation or customisation as marketing actions

\begin{tabular}{|c|c|}
\hline Customisation & Personalisation \\
\hline $\begin{array}{l}\text { - Focuses on sales specific information, things the } \\
\text { sales force would be more likely to know } \\
\text { - Creates incentives for the sales force to enter its } \\
\text { specific customer information into sales force } \\
\text { automation or contact management systems for } \\
\text { use in the entire organisation }\end{array}$ & $\begin{array}{l}\text { - Emphasises overall customer data quality, } \\
\text { accuracy, consistency and timeliness } \\
\text { - Develops marketing systems to manage } \\
\text { information about customer campaigns/offers } \\
\text { and success of particular campaigns/offers with } \\
\text { specific customers } \\
\text { - Disseminates information about the customer } \\
\text { throughout the organisation, so personalisation } \\
\text { efforts can continue across organisational } \\
\text { boundaries }\end{array}$ \\
\hline
\end{tabular}

research surveys and customer telephone calls. However, these capabilities were not as significantly related to personalisation capability as knowing which offers were sent and the response, information typically collected by direct marketers. Thus, even in a sample where direct marketing was not the primary focus of the organisations, a direct marketing 'orientation' relates to the ability to personalise interactions. This result in part may explain the success of direct marketers in developing personalisation capabilities over the internet, ${ }^{65}$ another area of future study.

This research has several limitations. First, the measures focus more on managing information about current customers than former or prospective customers. Secondly, their generic nature may make these scales less useful for assessing a technology (CRM or other specific system) without measuring the associated organisational capabilities. Thirdly, the generalisability of these scales beyond business-to-business services markets is not known.

\section{MANAGERIAL IMPLICATIONS}

The authors have developed several scales that can assist not only academic researchers but also practitioners in this growing area. The particular lessons from this research concerning developing large-scale databases and the importance of data quality that are relevant to managers are summarised below.

This research provides some hard evidence regarding customer information management practices that has been lacking, compared to the attention given to the development of CRM systems and the importance of collecting increasingly more customer information. Nothing in this analysis supports the notion that merely collecting huge amounts of information is useful in terms of developing and implementing a marketing strategy for competitive advantage. That none of the survey items relating to acquisition activities is associated with personalisation or customisation indicates that amassing large amounts of data, in and of itself, will not necessarily bring the firm closer to its marketing strategy objectives. Instead, managers might be advised to consider the type and quality of available information used in their organisations rather than force the broad adoption of a specific system or database.

Managers might consider the importance of specific types of information and its basic quality, depending on firm objectives, as summarised in Table 6. When seeking customisation as a competitive advantage, 
the importance of information collected by the sales force must be recognised and the focus placed keenly on incentives for salespersons to enter information into sales force and contact management systems. Less attention should be focused on overall marketing systems and capabilities. When personalisation is the marketing action for strategic gain, overall data quality should be focused on first. Data quality often is overlooked in the zeal to implement customer-focused systems and strategies. Personalisation requires, in addition to an emphasis on data quality, an emphasis on marketing (as opposed to sales) systems and capabilities that might be found in campaign management software systems. Also important to personalisation capability is the ability to disseminate information about the customer through the entire organisation, so that every customer communication takes each customer's uniqueness into account.

The good news for managers is that all of the elements in this study are to some degree under their control. The selection of the marketing actions to implement firm strategy (personalisation or customisation) and the development of customer information management capabilities can all be affected by managerial decisions. This paper seeks to help managers make these choices.

\section{APPENDIX 1: SCALE DEVELOPMENT}

Items with less than 10 per cent missing information were included in the analysis. Almost all variables had less than 5 per cent missing information. Variables were recoded to eliminate missing data. Recoding with ' 1 ' for blanks utilised the full sample while avoiding problems of biasing the correlation matrix upward, which might occur by replacing blank responses with means. The ' 1 ' in this case meant that the capability was absent in the firm. This procedure meant 209 observations could be retained, exceeding the 150 minimum usually recommended for exploratory factor analysis (EFA). ${ }^{66}$

Final constructs were developed through correlation analysis and EFA and then subjected to the rigours of CFA for convergent and discriminant validity at the item level. ${ }^{67}$ CFA results may be obtained from the authors. The primary differences between the hypothesised and final construct structure results from the simplification process that characterises this type of analysis.

When correlation analysis indicated that scale items were related, EFA (principal components analysis with a Varimax rotation) was used. The cutoff was 0.5 for individual item factor loadings ${ }^{68,69}$ and 1.0 for factor eigenvalues. The EFA results are reported in Table 3. This EFA of all seven constructs demonstrates convergent and discriminant validity at the item and construct level. The seven constructs each load on separate factors, with each factor explaining more than 5.0 per cent of the variance in the data.

Descriptive statistics for the final constructs and inter-item correlations are reported in Table 4. These statistics again support convergent and discriminant validity on the construct level. While many of the constructs are correlated, no correlation is so high $(>0.6)$ as to suggest not proceeding with the analysis. In addition, the variance inflation factor (VIF) is close to 1.0 for all variables, indicating that multicollinearity is not a concern in these data.

Cronbach's $\alpha$ provides scale reliability. All scales met the criteria of $\alpha>0.6$ for exploratory research and most are well above $0.70 .^{70-72}$ Exceptions were customisation and dissemination ( $\alpha=0.66,0.67$, respectively). 
APPENDIX 2: SURVEY

(Items included in final scales, complete listing of items available from authors)

\section{Independent variables (customer information management capabilities)}

\section{Information generation - New constructs}

Acquisition (new construct) $(1=$ never, $3=50$ per cent of the time, $5=100$ per cent of the time) Indicate the extent to which your unit acquires the following customer feedback from the following sources:
a. Response to web hits/enquiries
b. Response to e-mails
c. Marketing research surveys
d. Customer initiated phone calls

Person specificity, sales $(1=$ never, $3=50$ per cent of the time, $5=100$ per cent of the time)

For current customers what percentage of the time do those in your unit have the following information:
a. Contact name
b. Type of contact
c. Response to contact
d. Names of others involved in purchase

Person specificity, marketing $(1=$ never, $3=50$ per cent of the time, $5=100$ per cent of the time) For current customers what percentage of the time do those in your unit have the following information:
a. Marketing offers made
b. Marketing offers responded to
c. Method of contact
d. Timing of response to various marketing offers

Quality $(1=$ never, $3=50$ per cent of the time, $5=100$ per cent of the time)

a. When people in your unit access customer information, they find it is accurate

b. When people in your unit access customer information, they find it is consistent from one source or stored place to another

c. When people in your unit access customer information, they find it has been updated in a timely fashion

d. Overall, the data quality in your unit is $(1=$ poor, $3=$ moderate, $5=$ excellent)

Dissemination (from Kohli, et al. 1993) $(1=$ not at all, $3=$ moderate extent, $5=$ large extent)

a. Our business unit periodically circulates documents (eg reports, newsletters, news clippings) that provide information on our customers

b. When something important happens to a major customer of ours, the whole business unit knows about it within a short period

c. Data on customer purchase patterns are disseminated at all levels in this business unit on a regular basis

d. Marketing personnel in our department regularly exchange customer information with other departments

\section{Dependent variables}

\section{Personalisation capability (new} construct) $(1=$ never, $3=50$ per cent of the time, $5=100$ per cent of the time)

a. What percentage of the time your unit can track the response rate of offers by programme

b. What percentage of the time your unit 
can track the response rate of offers by segment

c. What percentage of the time your unit can track the response rate of offers by specific customers

\section{Customisation activity (from Milne and Boza, 1998, Glazer 1991)} $(1=$ not at all, $3=$ moderate extent, $5=$ large extent)

a. Products offered to the market depend on customer transaction information (a customer transaction is an exchange of goods or information with the customer)

b. The marketing effort of products depends on customer transaction information

c. Products are customised based on customer transaction information.

\section{Acknowledgments}

This research was funded by grants from the Direct Marketing Policy Center at the University of Cincinnati, The Institute for Interactive and Direct Marketing at DePaul University and University of Illinois, Department of Business Administration.

\section{References}

1 Cooper, B. L., Watson, H., Wixom, B. H. and Goodhue, D. (2000) 'Data warehousing supports corporate strategy at First American corporation', MIS Quarterly, Vol. 24, No. 4, pp. 547-567.

2 Morgan, R. M. and Hunt, S. D. (1994) 'The commitment-trust theory of relationship marketing', Journal of Marketing, Vol. 58, No. 3, pp. 20-38.

3 Webster, F. E., Jr. (1992) 'The changing role of marketing in the corporation', Journal of Marketing, Vol. 56, October, pp. 1-17.

4 Deighton, J. (1997) 'Commentary on exploring the implications of the internet for consumer marketing', Journal of the Academy of Marketing Science, Vol. 25, No. 4, pp. 347-351.

5 Ibid.

6 Glazer, R. (1991) 'Marketing in an information-intensive environment: Strategic implications of knowledge as an asset', Journal of Marketing, Vol. 55, October, pp. 1-19.

7 Day, G. S. (2000) 'Managing market relationships', Journal of the Academy of Marketing Science, Vol. 28, No. 1, pp. 18-32.

8 Deighton (1997) op. cit.

9 Glazer (1991) op. cit.
10 Pine, B. J. (1993) Mass Customization: The New Frontier in Business Competition, Harvard Business School Press, Cambridge, MA, USA.

11 Blattberg, R. C. and Deighton, J. (1991) 'Interactive marketing: Exploiting the age of addressability', Sloan Management Review, Vol. 33, Fall, pp. 5-14.

12 Ibid.

13 Deighton (1997) op. cit.

14 Ibid.

15 Glazer (1991) op. cit.

16 Bonoma, T. V. and Crittenden. V. L. (1988) 'Managing marketing implementation', Sloan Management Review, Vol. 29, Winter, pp. 7-14.

17 Dwyer, F. R., Schurr, P. H. and Oh, S. (1987) 'Developing buyer-seller relationships', Journal of Marketing, Vol. 51, April, 11-27.

18 Hoffman, D. L. and Novak, T. P. (1996) 'Marketing in hypermedia computer mediated environments: Conceptual foundations', Journal of Marketing, Vol. 60, July, pp. 50-68.

19 Ibid.

20 Alba, J., Lynch, J., Weitz, B., Janiszewski, C., Lutz, R., Sawyer, A. and Wood, S. (1997) 'Interactive home shopping: Consumer retailer and manufacturer incentives to participate in electronic marketplaces', Journal of Marketing, Vol 61, July, pp. 38-53.

21 Deighton (1997) op cit.

22 Deighton, J. (1996) 'The future of interactive marketing', Harvard Business Review, Vol. 74, November-December, pp. 151-160.

23 Ibid.

24 Pine (1993) op cit.

25 Day, G. S. (1999) The Market Driven Organization: Understanding, Attracting and Keeping Valuable Customers, Free Press, New York, NY, USA.

26 Peppers, D. and Rogers, M. (1997) Enterprise One to One: Tools for Competing in the Interactive Age, Currency Doubleday, New York, NY, USA.

27 Pickholz, J. W. (1994) 'Marketing to an audience of one: The new packaged goods marketing paradigm' (Editorial), Journal of Direct Marketing, Vol. 8, No. 2, pp. 2-6.

28 Kalakota, R. and Robinson, M. (1999) e-Business, Roadmap for Success, Addison-Wesley, Reading, MA, USA.

29 Wang, R. Y. (1998) 'A product perspective on total data quality management', Association for Computing Machinery. Communications of the ACM, Vol. 41, February, pp. 58-65.

30 Itami, H. and Roehl, T. W. (1987) Mobilizing Invisible Assets, Harvard University Press, Cambridge, MA, USA.

31 Sinkula, J. M., Baker, W. E. and Noordewier, T. (1997) 'A framework for market-based organizational learning: Linking values, knowledge and behavior', Journal of the Academy of Marketing Science, Vol. 25, No. 4, pp. 305-318.

32 Pentland, B. T. (1995) 'Information systems and organizational learning: The social epistemology of organizational knowledge systems', Accounting, 
Management and Information Technologies, Vol. 5, No. 1, pp. 1-21.

33 Slater, S. F. and Narver, J. C. (1995) 'Market orientation and the learning organization,' Journal of Marketing, Vol. 59, July, pp. 63-74.

34 Day, G. S. (1994) 'Continuous learning about markets', California Management Review, Vol. 36, Summer, pp. 9-31.

35 Holzner, B. and Marx, J. (1979) The Knowledge Application: The Knowledge System in Society, Alyn-Bacon, Boston, MA, USA.

36 Peppers and Rogers (1997) op. cit.

37 Jackson, R. and Wang, P. (1995) Strategic Database Marketing, NTC Publishing Group, Lincolnwood, IL, USA.

38 Wang, R. Y. and Strong, D. M. (1996) 'What data quality means to data consumers', Journal of Management Information Systems, Vol. 12, No. 4, pp. 5-34.

39 Jackson and Wang (1995) op. cit.

40 Sampler, J. L. (1998) 'Redefining industry structure for the information age', Strategic Management Journal, Vol. 19, Special Issue, pp. 343-355.

41 Peppers and Rogers (1997) op cit.

42 Strong, D. M., Lee, Y. W. and Wang, R. Y. (1997) 'Data quality in context,' Communications of the ACM, Vol. 40, No. 5, pp. 103-110.

43 Sampler (1998) op. cit.

44 Choudhury, V. and Sampler, J. L. (1997) 'Information specificity and environmental scanning: An economic perspective', MIS Quarterly, Vol. 21, March, pp. 25-53.

45 Peppers, D. and Rogers, M. (2001) One to One B2B: Customer Development Strategies for the Business-to-Business World, Currency-Doubleday, New York, NY, USA.

46 Menon, A. and Varadarajan, P. R. (1992) 'A model of marketing knowledge use within firms', Journal of Marketing, Vol. 56, October, pp. 53-71.

47 Kohli, A. K., Jaworski, B. J. and Kumar, A. (1993) 'MARKOR: A measure of market orientation,' Journal of Marketing Research, Vol. 30, April, pp. 467-478.

48 DeVellis, R. F. (1991) Scale Development: Theory and Applications, Sage Publications, Newbury Park, CA, USA.
49 Kohli et al. (1993) op. cit.

50 Glazer (1991) op. cit.

51 Milne, G. R. and Boza, M. E. (1998) 'A business perspective on database marketing and consumer privacy practices', Working Paper Report Number 98-110, Marketing Science Institute, Cambridge, MA, USA

52 Wang and Strong (1996) op. cit.

53 Menon and Varadarajan (1992) op. cit.

54 Kohli et al. (1993) op. cit.

55 Deighton (1997) op. cit.

56 Deighton (1996) op. cit.

57 Day (1997) op. cit.

58 Glazer (1991) op. cit.

59 Milne and Boza (1998) op. cit.

60 Sudman, S. (1976) Applied Sampling, Academic Press, New York, NY, USA.

61 Ward's Business Directory of US Private and Public Companies Volume 5: Ranked By Sales Within 4-Digit SIC (1999) Gale Press, Detroit, MI, USA.

62 Ward's Business Directory of US Private and Public Companies Volume 8: Ranked By Sales Within 9-Digit NAICS (1999), Gale Press, Detroit, MI, USA.

63 Porter, M. (1985) Competitive Advantage, The Free Press, New York, NY, USA.

64 Powell, T. C. and Dent-Micallef, A. (1997) 'Information technology as competitive advantage: The role of human, business and technology resources', Strategic Management Journal, Vol. 19, No. 5, pp. 375-405.

65 Roberts, M. L. (2002) Interactive Marketing: Integrating Online and Offline Strategies, McGraw-Hill Irwin, New York, NY, USA.

66 Hinkin, T. (1998) 'A brief tutorial for the development of measures for use in survey questionnaires', Organizational Research Methods, Vol. 1, No. 1, pp. 104-121.

67 Ibid.

68 Hair, J. F. (1979) Multivariate Data Analysis, with Readings, PPC, Tulsa, OK, USA.

69 Nunnally, J. C. (1978) Psychometric Theory, McGraw-Hill, New York, NY, USA.

70 Ibid.

71 Hair (1979) op. cit.

72 Nunnally, J. C. (1967) Psychometric Theory, McGraw-Hill, New York, NY, USA. 